\title{
Management of Yellow Mosaic Disease of Mungbean Against Mungbean Yellow Mosaic Virus (MYMV) in Bangladesh
}

\author{
Md. S. Islam ${ }^{1}$, Md. B. Hossain ${ }^{1}$, Saleh A. Shahriar ${ }^{2}$, Fatema Begum ${ }^{1} \&$ Md. N. H. Sani ${ }^{3}$ \\ ${ }^{1}$ Department of Plant Pathology, Sher-e-Bangla Agricultural University, Dhaka, Bangladesh \\ ${ }^{2}$ Faculty of Agriculture, Sher-e-Bangla Agricultural University, Dhaka, Bangladesh \\ ${ }^{3}$ Department of Horticulture, Sher-e-Bangla Agricultural University, Dhaka, Bangladesh \\ Correspondence: Saleh A. Shahriar, Faculty of Agriculture, Sher-e-Bangla Agricultural University, Dhaka-1207, \\ Bangladesh. E-mail: shahriar777.ss@gmail.com
}

Received: November 16, 2018; Accepted: December 7, 2018; Published: December 19, 2018

\begin{abstract}
The prime aim of the study was to manage of Yellow mosaic disease of mungbean against Mungbean yellow mosaic virus (MYMV) by using one newly release botanical nutrient and through three selected insecticides. BARI (Bangladesh Agricultural Research Institute) released variety BARI mung-5, three insecticides (Imidacloprid, Acmix and Sobicron) and one botanical nutrient PPN (Peak performance nutrients) were used in the experiment. The plants were grown for pulse production and natural inoculums were relied upon for the infection of $M Y M V$. Growth parameters, yield attributes and physiological features were significantly influenced by the application of selected insecticides and PPN combinations. Disease incidence and disease severity of $M Y M V$ were significantly varied among the treatments. Application of Imidacloprid with PPN combination gave the lowest disease incidence (3.13, 5.24 and $6.24 \%$ per plot and $14.33,15.49$ and $21.87 \%$ per plant) at 30,40 and 50 DAS, respectively while the highest disease incidence $(7.77,13.70$ and $19.24 \%$ per plot and 39.33, 48.20 and 56.63\% per plant) were found in control at 30, 40 and 50 DAS, respectively. Application of Imidacloprid with PPN also gave the lowest disease severity $(5.00,6.00$ and $13.33 \%$ at 30,40 and 50 DAS, respectively while the highest disease severity (27.33, 35.00 and $45.00 \%$ ) at 30, 40 and $50 \mathrm{DAS}$, respectively were measured in control treatment when no insecticides and PPN was used. If the disease is established once in the field then it is difficult to manage. As the disease is transmitted by vector (whitefly), the growers are suggested to control the vector populations before reaching economic damage and severe disease infection.
\end{abstract}

Keywords: yellow mosaic disease, Mungbean yellow mosaic virus, management, insecticides, Peak Performance Nutrients (PPN)

\section{Introduction}

Mungbean (Vigna radiata L.) belongs to the family Fabaceae and sub-family Papilonaceae, is a good source of protein, carbohydrate and vitamin. Being an important short-duration Kharif grain legume, mungbean is grown extensively in major tropical and sub-tropical countries of the world (Biswass et al., 2008). Mungbean is the fifth important pulse crop of Bangladesh. It is a drought tolerant, grown twice in a year and fits well in Bangladesh crop rotation program. This classification is convenient in judging the economic importance of the pest, especially their influence on seed yield, and in devising control measures (Akhtar et al., 2003). Mungbean is attacked by different species of insect pests but sucking insect pests (aphid, jassid, white leaf hopper and whitefly) are of the importants (Islam et al., 2008). These insect pests not only reduce the vigor of the plant by sucking the sap but also transmit different diseases particularly viral diseases and affect photosynthesis as well. Pest appearance, population fluctuation, infestation rate and crop yield are very much dependent on sowing time (Hossain et al, 2004, Bisht et $a l, 1988$ ). Most of the farmer's usually sown mungbean just after harvesting them Rabi crops without considering optimum sowing dates (Hossain et al., 2009). The reasons of low yield of mungbean are numerous but yield losses due to insect pest complex are distinct one. Mungbean is attacked by different species of insect pests. Insect pests that attack mungbean can be classified based on their appearance in the field as it related to the phonology of mungbean plant (Shad et al., 2005, Gill et al., 1999). They are stem feeders, foliage feeders, pod feeders and storage pests. Mungbean crop is affected by various pathogens among them Mungbean Yellow Mosaic Virus $(M Y M V)$ is the most important and widely distributed. MYMV causes irregular yellow and green patches on older leaves resulting complete yellowing leaves. Affected plants produce less number of flowers, pods and seeds. 
This disease is destructive, and widespread heavy loss annually. It was first identified in India in 1955 and is naturally transmitted by whitefly (Bemisia tabaci Genn), but not by mechanical inoculation or by seed (Pathak et $a l, 2004)$. It infects mungbean, soybean, mothbean, cowpea and some hosts of the family Malvaceae and Solanaceae. Yellow mosaic is reported to be the most destructive viral disease not only in Bangladesh, but also in India, Pakistan, Sri Lanka and adjacent areas of South East Asia (Shah et al., 2007). MYMV belongs to the genus Begomovirus of the family Geminivirideae. The virus has geminate particle morphology $(20 \times 30 \mathrm{~nm})$ and the coat protein encapsulates circular, single stranded DNA genome of approximately $2.8 \mathrm{~kb}$. In Pakistan, the virus has been partially characterized and identified on the basis of Polymerase Chain Reaction (PCR) and epitope profile and DNA sequence (Hossain et al., 2004). Inheritance studies with $M Y M V$ have also been conducted. Epidemiological factors play a crucial role in the development of $M Y M V$ and white fly population (Shad et al, 2006). The proper time of application of insecticides could be helpful not only to manage whitefly but also virus minimizing by the number of sprays. The study of epidemiological factors determined the most conducive environment for the application of pesticides at right time, enhancing the yield of this crop (Sunil et al., 2010).

The objectives of the experiment were to evaluate the efficacy and potentiality of selected Insecticides and Peak Performance Nutrients (PPN) to manage the Yellow mosaic disease of Mungbean against Mungbean yellow mosaic virus (MYMV) and minimizing the vector populations.

\section{Materials and Methods}

\subsection{Experimental Materials}

An experiment on management of yellow mosaic disease of mungbean was conducted in the field of SAU central Farm of Sher-e-Bangla Agricultural University, Dhaka-1207, Bangladesh during April to July, 2017. Mungbean variety namely, BARI mung-5, was used as planting material. The selected insecticides namely Imidacloprid, Acmix and Sobicron were collected from local market and PPN was collected from China through representative country dealers of Bangladesh.

\subsection{Design and Layout of Experiment}

The experiment was laid out in a Randomized Complete Block Design (RCBD) with three replications and eight treatments include a control, there were $24(3 \times 8)$ unit plots. The size of each unit plot was $(3 \mathrm{~m} \times 2 \mathrm{~m})$. Plot to plot distances were $1 \mathrm{~m}$. The treatments of the present experiment were randomly distributed into the experimental plot.

\subsection{Experimental Treatments}

Considering insecticides and PPN the treatments are

$\mathrm{T}_{1}=$ Peak Performance Nutrients (PPN) (2 g/L water)

$\mathrm{T}_{2}=$ Imidacloprid $(1 \mathrm{ml} / \mathrm{L}$ water $)+\mathrm{PPN}(2 \mathrm{~g} / \mathrm{L}$ water $)$

$\mathrm{T}_{3}=$ Imidacloprid $(1 \mathrm{ml} / \mathrm{L}$ water $)$

$\mathrm{T}_{4}=$ Sobicron $(1 \mathrm{ml} / \mathrm{L}$ water $)+$ PPN ( $2 \mathrm{~g} / \mathrm{L}$ water $)$

$\mathrm{T}_{5}=$ Sobicron $(1 \mathrm{ml} / \mathrm{L}$ water $)$

$\mathrm{T}_{6}=\operatorname{Acmix}(1 \mathrm{ml} / \mathrm{L}$ water $)+\mathrm{PPN}(2 \mathrm{~g} / \mathrm{L}$ water $)$

$\mathrm{T}_{7}=\operatorname{Acmix}(1 \mathrm{ml} / \mathrm{L}$ water $)$

$\mathrm{T}_{8}=$ Control (no insecticides and PPN)

\subsection{Disease Symptoms in Infected plants}

Virus like symptoms were observed under field conditions depending upon the virus and crop variety. The infected plants were showing yellow specks along the vein lets and spreading over the lamina, the pods became thin and curled upward. In case of susceptible cultivars the whole leaves became yellow. The next trifoliate leaf emerging from the growing apex was showing irregular yellow and green patches alternating each other. The leaf size was not much affected. The plants showing such symptoms were rated as MYMV-infected plants (Fig. 1). The other type of symptoms were leaf rugosty, crinkling and distortion. The leaf size was increased and more green than normal colour.

\subsection{Identification of Disease Incidence of Mungbean Yellow Mosaic Virus (MYMV)}

Based on studying typical symptoms of $M Y M V$ were observed. The Mungbean plants were inspected every day until harvest and the symptoms appeared in the mungbean plants was noted. The growth stage of the plants were categorized as follows- 
Early stage- 3 weeks after seed sowing

Mid stage- 2 weeks after early stage, and

Late stage- after mid stage up to harvest.

The disease incidence was expressed in percentage on the basis of stage as well as total i.e., average of three stages.

The percent disease incidence was calculated by using the following formula:

$\%$ Disease Incidence $=\quad \mathrm{X}_{1} \quad \times 100$

Where,

$\mathrm{X}=$ Total number of plants

$\mathrm{X}_{1}=$ Number of infected plants

\subsection{Disease Incidence (\%) per Plot and per Plant}

Incidence of mosaic disease were recorded at before and after flowering. Ten plants were randomly selected from each plot and the mosaic symptoms were observed carefully for the collection of data. Data on mosaic disease incidence were recorded at an interval of 10 days commencing from first incidence and continued up to 3 times.

\subsection{Disease Severity (\%) per Plot}

Severity of mosaic disease were recorded from ten plants were randomly selected in each plot and observed carefully for the collection of data. Data on mosaic disease severity were recorded at an interval of 10 days commencing from first severity and continued up to 3 times.

\subsection{Chlorophyll Content in Leaves per Plant}

The net chlorophyll content in the leaves of the selected plants was recorded with the help of "S-pad", which is an advanced technology to directly measure the chlorophyll content in plant leaf at 30,40 and 50 days after sowing (DAS). In each reading single leaf was held by the machine three times at three location of the leaf then the machine automatically average the data and gave the value.

\subsection{Collection of Data and Statistical Analysis}

The data are collected at 30, 40 and 50 days after sowing (DAS). The collected data were statistically analyzed by using the ANOVA technique. The test of significance of all parameters was done. The Duncan's Multiple Range Test (DMRT) with Least Significant Difference value was determined with appropriate levels of significance and the means were tabulated. The mean comparison was carried out by DMRT technique. The statistical package MSTAT-C was used for this purpose.

\section{Results and Discussion}

3.1 Effect Treatments on Disease Incidence (\%) per plot of Mungbean yellow mosaic virus (MYMV) at 30, 40 and 50 DAS respectively

The highest disease incidence was found in T8 $((7.77,13.70$ and $19.24 \%)$ which is just above than T1 $(7.33,12.83$ and $17.90 \%)$. The lowest disease incidence was found in $\mathrm{T} 2(3.13,5.24$ and $6.24 \%)$. The moderate disease incidence was found by any one application of T5 $(4.36,8.50$ and $8.51 \%)$, T7 (5.03, 9.43 and $11.97 \%)$ and T4 $(5.63,10.27$ and $13.40 \%) \mathrm{T} 3(6.06,11.33$ and $14.83 \%)$ T6 (6.63, 12.13 and $16.60 \%)$.

3.2 Effect of Treatments on Disease Incidence (\%) per plant of Mungbean yellow mosaic virus (MYMV) at 30, 40 and 50 DAS respectively

In case of disease incidence per plant, the highest disease incidence was found in $\mathrm{T}_{8}(39.33,48.20$ and 56.63\%) which is just above $\mathrm{T}_{1}(37.67,43.90$ and $52.53 \%)$. The lowest disease incidence was recorded in $\mathrm{T}_{2}(14.33,15.49$ and $21.87 \%)$. Moderate results were observed by anyone application of $\mathrm{T}_{5}(18.27,26.70$ and $38.93 \%), \mathrm{T}_{7}(22.87$, 30.44 and $35.10 \%), \mathrm{T}_{4}(28.51,35.12$ and $38.50 \%), \mathrm{T}_{3}(31.73,37.77$ and $43.20 \%)$ and $\mathrm{T}_{6}(34.83,41.00$ and $48.23 \%)$.

\subsection{Effect of Treatments on Disease Severity (\%) of Mungbean yellow mosaic virus (MYMV) at 30, 40 and 50 DAS respectively}

The highest disease severity was found in $\mathrm{T}_{8}(27.33,35.00$ and $45.00 \%)$, followed by $\mathrm{T}_{1}(26.33,33.00$ and $41.33 \%)$. The lowest disease severity was found in $\mathrm{T}_{2}(5.00,6.00$ and $13.33 \%)$. Moderate observations were recorded by any one application of $\mathrm{T}_{5}(10.00,17.33$ and $23.67 \%), \mathrm{T}_{7}(15.33,21.00$ and $25.12 \%), \mathrm{T}_{4}(19.00,24.33$ and $27.00 \%)$, $\mathrm{T}_{3}(21.33,28.67$ and $33.33 \%), \mathrm{T}_{6}(24.67,31.67$ and $37.67 \%)$. 


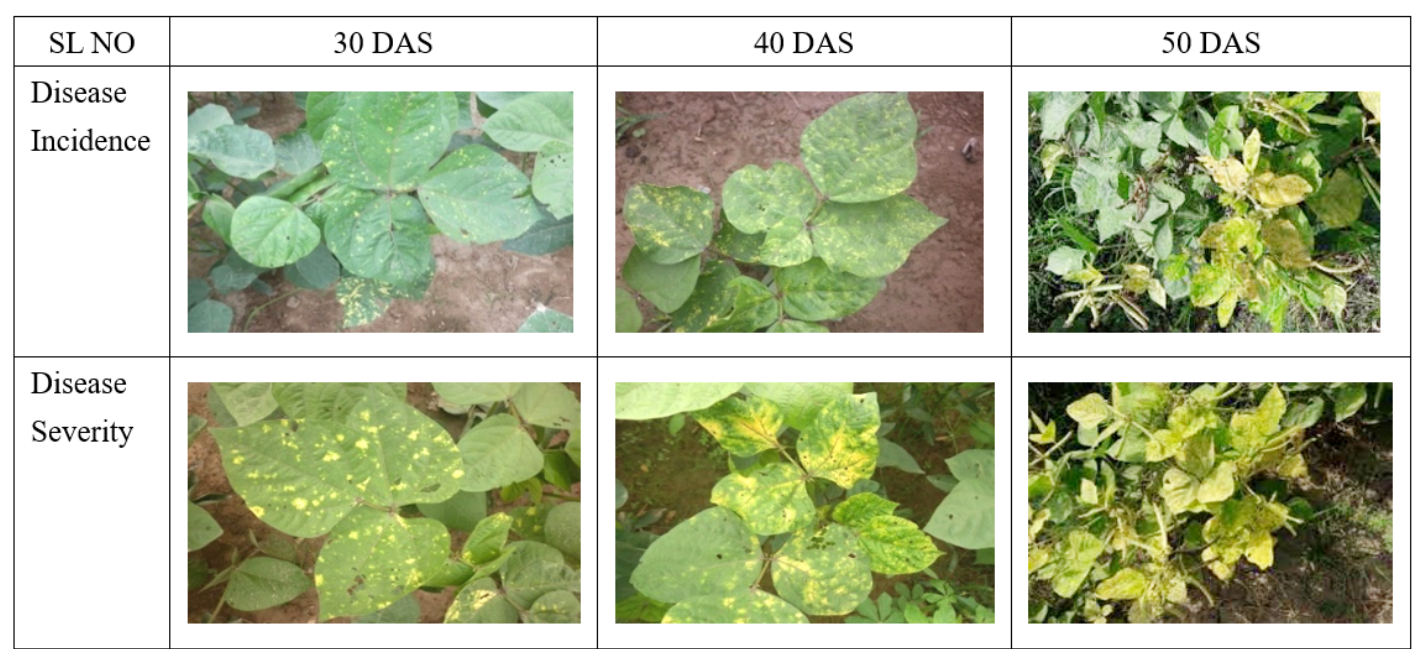

Figure 1. Effect of Treatments on Disease Incidence and Disease Severity at 30, 40 and 50 DAS respectively

Table 1. Effect of Treatments on Disease Incidence per plot (D.I/plot) and per plant (D.I/plant) and Disease Severity

\begin{tabular}{llll}
\hline \multicolumn{1}{l}{ Treatments } & \%D.I/plot & \%D.I/plant & \%Severity \\
\hline \multicolumn{2}{l}{ Effect of Treatments on Disease Incidence per plot (D.I/plot) and per plant (D.I/plant) and Disease Severity at } \\
30 DAS. & \multicolumn{3}{l}{} \\
\hline $\mathrm{T}_{1}$ & $7.33 \mathrm{ab}$ & $37.67 \mathrm{a}$ & $26.33 \mathrm{ab}$ \\
$\mathrm{T}_{2}$ & $3.13 \mathrm{~g}$ & $14.33 \mathrm{~g}$ & $5.00 \mathrm{~g}$ \\
$\mathrm{~T}_{3}$ & $6.06 \mathrm{~cd}$ & $31.73 \mathrm{c}$ & $21.33 \mathrm{c}$ \\
$\mathrm{T}_{4}$ & $5.63 \mathrm{de}$ & $28.51 \mathrm{~d}$ & $19.00 \mathrm{~d}$ \\
$\mathrm{~T}_{5}$ & $4.36 \mathrm{f}$ & $18.27 \mathrm{f}$ & $10.00 \mathrm{f}$ \\
$\mathrm{T}_{6}$ & $6.63 \mathrm{bc}$ & $34.83 \mathrm{~b}$ & $24.67 \mathrm{~b}$ \\
$\mathrm{~T}_{7}$ & $5.03 \mathrm{ef}$ & $22.87 \mathrm{e}$ & $15.33 \mathrm{e}$ \\
$\mathrm{T}_{8}$ & $7.77 \mathrm{a}$ & $39.33 \mathrm{a}$ & $27.33 \mathrm{a}$ \\
$\mathrm{LSD}$ & 0.764 & 1.774 & 1.666 \\
$\mathrm{CV}_{0.01}$ & 5.49 & 2.57 & 3.66 \\
\hline
\end{tabular}

Effect of Treatments on Disease Incidence per plot (D.I/plot) and per plant (D.I/plant) and Disease Severity at 40 DAS.

\begin{tabular}{llll}
\hline $\mathrm{T}_{1}$ & $12.83 \mathrm{~b}$ & $43.90 \mathrm{~b}$ & $33.00 \mathrm{~b}$ \\
$\mathrm{~T}_{2}$ & $5.24 \mathrm{~h}$ & $15.49 \mathrm{~h}$ & $6.00 \mathrm{~g}$ \\
$\mathrm{~T}_{3}$ & $11.33 \mathrm{~d}$ & $37.77 \mathrm{~d}$ & $28.67 \mathrm{c}$ \\
$\mathrm{T}_{4}$ & $10.27 \mathrm{e}$ & $35.12 \mathrm{e}$ & $24.33 \mathrm{~d}$ \\
$\mathrm{~T}_{5}$ & $8.50 \mathrm{~g}$ & $26.70 \mathrm{~g}$ & $17.33 \mathrm{f}$ \\
$\mathrm{T}_{6}$ & $12.13 \mathrm{c}$ & $41.00 \mathrm{c}$ & $31.67 \mathrm{~b}$ \\
$\mathrm{~T}_{7}$ & $9.43 \mathrm{f}$ & $30.44 \mathrm{f}$ & $21.00 \mathrm{e}$ \\
$\mathrm{T}_{8}$ & $13.70 \mathrm{a}$ & $48.20 \mathrm{a}$ & $35.00 \mathrm{a}$ \\
$\mathrm{LSD}$ & 1.853 & 1.415 \\
$\mathrm{CV} \%$ & 0.352 & 2.14 & 2.28 \\
\hline
\end{tabular}

Effect of Treatments on Disease Incidence per plot (D.I/plot) and per plant (D.I/plant) and Disease Severity at

\begin{tabular}{|c|c|c|c|}
\hline $\mathrm{T}_{1}$ & $17.90 \mathrm{~b}$ & $52.73 \mathrm{~b}$ & $41.33 \mathrm{~b}$ \\
\hline$T_{2}$ & $6.24 \mathrm{~g}$ & $21.87 \mathrm{~h}$ & $13.33 \mathrm{~h}$ \\
\hline $\mathrm{T}_{3}$ & $14.83 \mathrm{c}$ & $43.20 \mathrm{~d}$ & $33.33 \mathrm{~d}$ \\
\hline $\mathrm{T}_{4}$ & $13.40 \mathrm{~d}$ & $38.50 \mathrm{e}$ & $27.00 \mathrm{e}$ \\
\hline $\mathrm{T}_{5}$ & $8.51 \mathrm{f}$ & $38.93 \mathrm{~g}$ & $23.67 \mathrm{~g}$ \\
\hline $\mathrm{T}_{6}$ & $16.60 \mathrm{~b}$ & $48.23 \mathrm{c}$ & $37.67 \mathrm{c}$ \\
\hline $\mathrm{T}_{7}$ & $11.97 \mathrm{e}$ & $35.10 \mathrm{f}$ & $25.12 \mathrm{f}$ \\
\hline $\mathrm{T}_{8}$ & $19.24 \mathrm{a}$ & $56.63 \mathrm{a}$ & $45.00 \mathrm{a}$ \\
\hline
\end{tabular}




\begin{tabular}{llll}
\hline $\mathrm{LSD}_{0.01}$ & 1.340 & 1.938 & 2.097 \\
$\mathrm{CV} \%$ & 4.09 & 2.11 & 3.17 \\
\hline
\end{tabular}

$\mathrm{T}_{1}(\mathrm{PPN}), \mathrm{T}_{2}$ (Imidacloprid with PPN), $\mathrm{T}_{3}$ (Imidacloprid), $\mathrm{T}_{4}$ (Sobicron with PPN), $\mathrm{T}_{5}$ (Sobicron), $\mathrm{T}_{6}$ (Acmix with $\mathrm{PPN}), \mathrm{T}_{7}$ (Acmix) and $\mathrm{T}_{8}$ (Control).

\subsection{Effect of Treatments on Net Chlorophyll Content $\left(\mu \mathrm{mol} \mathrm{m} \mathrm{m}^{-2} \mathrm{~s}^{-1}\right.$ of Healthy plants and Infected plants}

In healthy plant, the highest net chlorophyll content was found in $\mathrm{T}_{2}$ (56.30) followed by $\mathrm{T}_{5}(54.20), \mathrm{T}_{7}(52.23)$, $\mathrm{T}_{4}(50.40), \mathrm{T}_{3}$ (48.17), and $\mathrm{T}_{6}$ (46.23). The lowest net chlorophyll content was recorded in $\mathrm{T}_{8}(41.80)$. In infected plant, the highest net chlorophyll content was found in $T_{2}$ (28.90), followed by $T_{5}$ (27.43) and $\mathrm{T}_{7}$ (26.37). The moderate chlorophyll content was found in $\mathrm{T}_{6}(21.53), \mathrm{T}_{3}$ (22.83), and $\mathrm{T}_{4}$ (24.43). The lowest net chlorophyll content was recorded in $T_{8}(18.23)$ preceded by $T_{1}$ (19.63). These results are clearly shown in Figure 2.

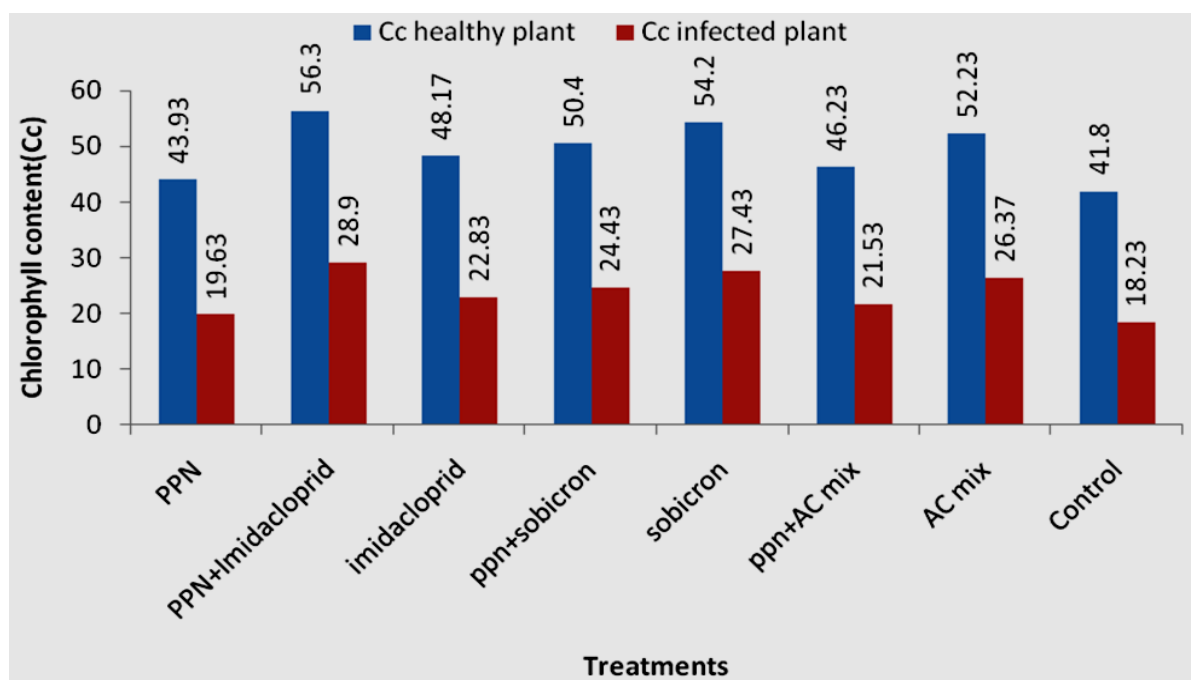

Figure 2. Graphical presentation of Chlorophyll Content in Healthy plants and Infected plants.

\subsection{Relationship between chlorophyll content $\left(\mu \mathrm{mol} \mathrm{m}^{-2} \mathrm{~s}^{-1}\right)$ and Disease Incidence (\%) per Plant}

Different treatments that were used in the present study regarding chlorophyll content $\left(\mu\right.$ mol m $\left.\mathrm{m}^{-2} \mathrm{~s}^{-1}\right)$ and disease incidence (\%), it is revealed that increased chlorophyll content was observed with decreased disease incidence. The highest chlorophyll content was found in $\mathrm{T}_{2}(28.90 \%)$ followed by $\mathrm{T}_{5}(27.43 \%)$ and $\mathrm{T}_{7}(26.37 \%)$ where control treatment showed the lowest chlorophyll content because of the highest disease incidence. As depicted in the figure 3.

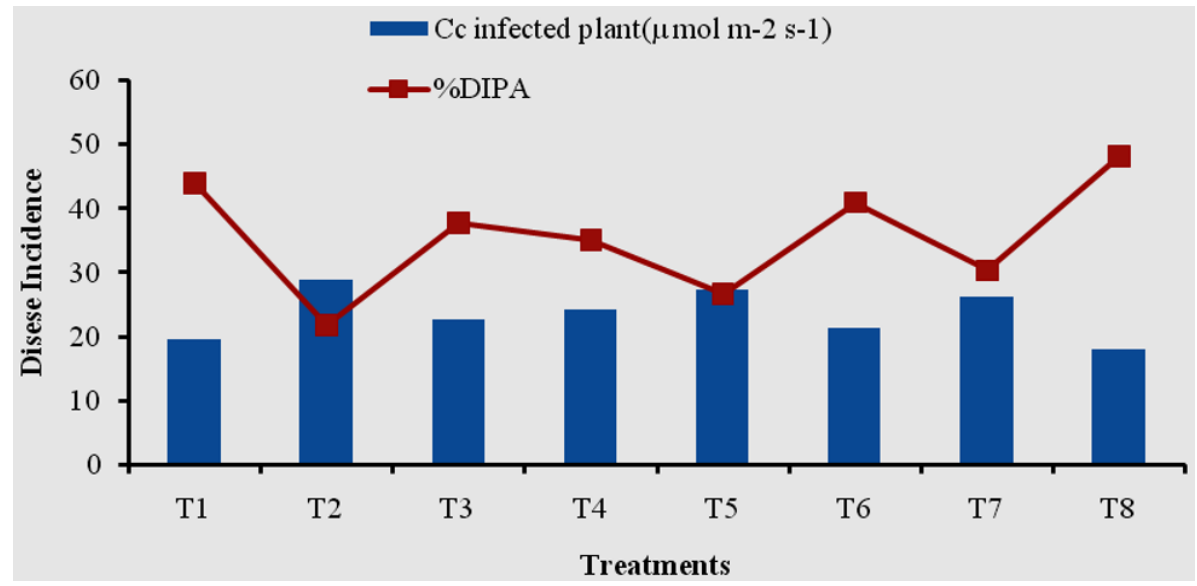

Figure 3. Relationship between Chlorophyll Content and Disease Incidence (\%) per plant

$\mathrm{T}_{1}$ (PPN), $\mathrm{T}_{2}$ (Imidacloprid with PPN), $\mathrm{T}_{3}$ (Imidacloprid), $\mathrm{T}_{4}$ (Sobicron with PPN), $\mathrm{T}_{5}$ (Sobicron), $\mathrm{T}_{6}$ (Acmix with $\mathrm{PPN}), \mathrm{T}_{7}$ (Acmix) and $\mathrm{T}_{8}$ (Control). 


\subsection{Relationship between Chlorophyll Content ( $\left.\mu \mathrm{mol} \mathrm{m}^{-2} \mathrm{~s}^{-1}\right)$ and Disease Severity (\%)}

Different treatments that were used in the present study regardin gchlorophyll content $\left(\mu \mathrm{mol} \mathrm{m}^{-2} \mathrm{~s}^{-1}\right)$ and disease severity (\%), it is revealed that increased chlorophyll content was observed with decreased disease severity. The highest chlorophyll content was found in $\mathrm{T}_{2}(28.90 \%)$ followed by $\mathrm{T}_{5}(27.43 \%)$ and $\mathrm{T}_{7}(26.37 \%)$ where control treatment showed lowest chlorophyll content because of highest disease severity. As depicted in the figure 4 .

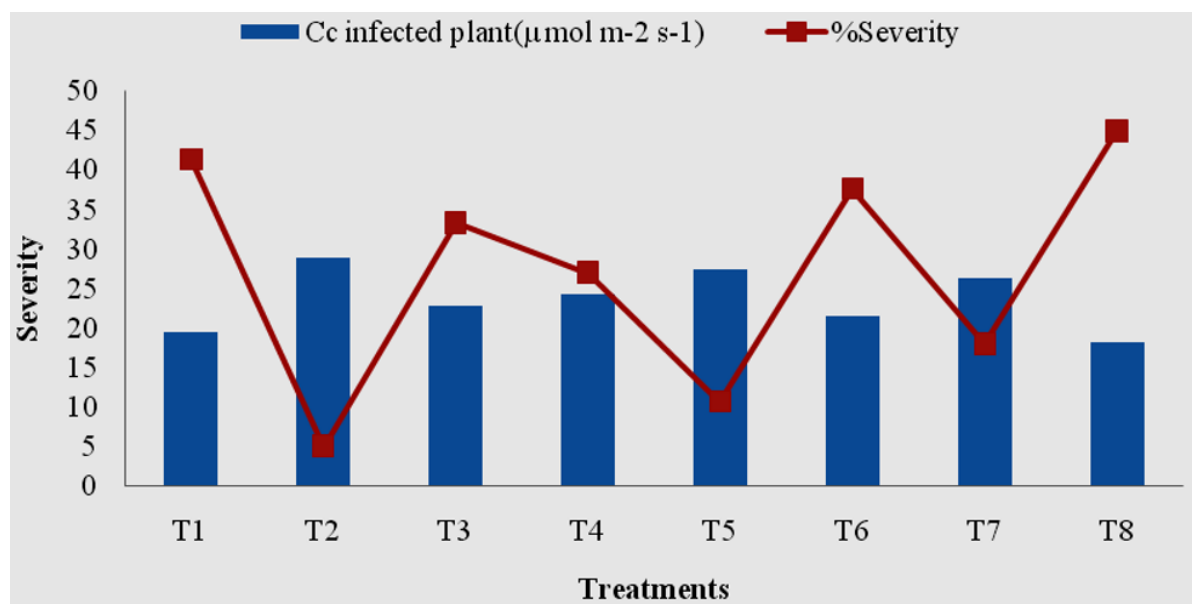

Figure 4. Relationship between Chlorophyll Content and Disease Severity (\%)

$\mathrm{T}_{1}$ (PPN), $\mathrm{T}_{2}$ (Imidacloprid with PPN), $\mathrm{T}_{3}$ (Imidacloprid), $\mathrm{T}_{4}$ (Sobicron with PPN), $\mathrm{T}_{5}$ (Sobicron), $\mathrm{T}_{6}$ (Acmix with $\mathrm{PPN}), \mathrm{T}_{7}$ (Acmix) and $\mathrm{T}_{8}$ (Control).

\section{Conclusion}

From the present study it has been observed that, the highest disease incidence was found when no insecticides and PPN is used followed by PPN and the lowest disease incidence was found when Imidacloprid with PPN is used, which found in both observations for per plot and per plant at 30,40 and 50 DAS respectively. From this study it may be concluded that the application of Imidachloprid in combination with PPN (Peak Performance Nutrients) showed promising performance in management of Yellow mosaic disease of Mungbean against Mungbean yellow mosaic virus (MYMV) contributing yield and yield attributes. Thus the farmer may be suggested to use this combination of treatments for the management of Yellow mosaic disease of Mungbean. However, further studies are needed to be carried out for a consecutive years including more options as management practices in different Agro-ecological zones (AEZs) of Bangladesh.

\section{References}

Akhtar, K. P., \& Haq, M. A. (2003). Standardization of a graft inoculation method for the screening of mungbean germplasm against Mungbean yellow mosaic virus (MYMV). Plant Pathol, 19, 257-259. https://doi.org/10.5423/PPJ.2003.19.5.257

Akhtar. K. P., \& Khan, M. S. L. (2002). Modified scale for the assessment of cotton leaf curl virus (CL('uV). Ind Phytopathol, 14, 88-90.

Bakar, M. A., Afzal, M. A., Hamid, A., Haque, M. M., \& Aktar, M. S. (2004). Blackgram in Bangladesh. Lentil Blackgram and Mungbean Development Pilot Project, Publication No.25, Pulses Research Centre, BARI, Gazipur.

Bisht, I. S., Shamsher, S., Dabas, B. S., \& Sing, S. (1988). Effect of yellow mosaic virus on growth components and yield of four promising cultivars of mungbean. Ind J. of Mycology and Plant Pathol, 18(2), 204-205.

Biswass, K. K., Malathi, V. G., \& Varma, A. (2008). Diagnosis of symptom less yellow mosaic begomovirus infection in pigeon pea by using cloned mungbean yellow mosaic India virus a problem. J. of Plant Biochemistry and Biotech, 17(1), 9-14. https://doi.org/10.1007/BF03263253

Gill, E. Z. (1999). Effect of mungbean yellow mosaic virus on yield components in mungbean cultivar. Insect Environment, 5(3), 112-113.

Gupta, M. P., \& Pathak, R. K. (2009). Bioefficacy of neem products and insecticides against the incidence of whitefly, yellow mosaic virus and pod borer in Black gram. Natural product radiance, 8(2), 133-136. 
Hamid, S., \& Robinson, D. J. (2004). Begomoviruses from mungbeans in Pakistan: Epitope profiles, DNA A sequences and phytogentic relationships. Archives of Virology, 149, 809-819. https://doi.org/10.1007/s00705003-0256-9

Hossain, M. A., Ferdous, J., Sarkar, M. A., \& Rahman, M. A. (2004). Insecticidal management of thrips and pod borer in mungbean. Bangladesh J. of Agric Res Institute, 29(3), 347-356.

Hossain, M. A., Islam, K. M. S., \& Mondal, A. T. M. A. I. (2000). Effect of sowing date on lentil aphid, aphis craccivora koch infestation and yield contributing characters of lentil (Lens culinaris Medik), 8, 115-117.

Hossain, M. A., Prodhan, M. Z. H., \& Sarkar, M. A. (2009). Sowing Dates: A Major Factor on the Incidence of Major Insect Pests and Yield of Mungbean. J. of Agric Rural Development, 127-133.

Islam, M. S., Latif, M. A., Ali, M., \& Hossain, M. S. (2008). Population dynamics of white fly on some recommended mungbean varieties in Bangladesh and its impact on incidence of mungbean yellow mosaic virus disease and yield. International J. of Sustain Agric Tech., 5(4), 41-46.

Pathak, A. K., \& Jhamaria, S. L. (2004). Evaluation of mungbean (Vigna radiata L.) varieties to yellow mosaic virus. J. of Mycology and Plant Pathol, 34(1), 64-65.

Qazi, J., Ilyas, M., Mansoor, S., \& Briddon, R. W. (2007). Legume yellow mosaic viruses: genetically isolated begomoviruses. Molecular Plant Pathol, 8(4), 343-348. https://doi.org/10.1111/j.1364-3703.2007.00402.x

Shad, N., Mughal, S. M., \& Bashir, M. (2005). Transmission of mungbean yellow mosaic Begomovirus (MYMV). Pak J. Phytopathol, 17(2), 141-143.

Shad, N., Mughal, S. M., Farooq, K., \& Bashir, M. (2006). Evaluation of mungbean germplasm for resistance against mungbean yellow mosaic begomovirus. Pak J. of Botany, 38(2), 449-457.

Shah, J. M., Ahmad, A., Hussain, M., Malik, Yousaf, M., \& Ahmad, B. (2007). Efficiency of different insecticides against sucking insect-pest complex and effect on the growth and yield of mungbean (Vigna radiata L.). Pak J. of Entomol, 29(2), 83-86.

Sunil, C. D., \& Singh, B. (2010). Seed treatment and foliar application of insecticides and fungicides for management of cercospora leaf spots and yellow mosaic of mungbean (Vigna radiata). International J. of Pest Management, 56(4), 309-314. https://doi.org/10.1080/09670874.2010.496875

\section{Copyrights}

Copyright for this article is retained by the author(s), with first publication rights granted to the journal.

This is an open-access article distributed under the terms and conditions of the Creative Commons Attribution license (http://creativecommons.org/licenses/by/4.0/). 